\title{
Anti-Inflammatory Phenolic Metabolites from the Edible Fungus Phellinus baumii in LPS-Stimulated RAW264.7 Cells
}

\author{
Seulah Lee ${ }^{1}$, Dahae Lee ${ }^{1,2}$, Tae Su Jang ${ }^{3}$, Ki Sung Kang ${ }^{2}$, Joo-Won Nam ${ }^{4}$, Hae-Jeung Lee ${ }^{5}$ and \\ Ki Hyun Kim ${ }^{1, *}$ \\ 1 School of Pharmacy, Sungkyunkwan University, Suwon 16419, Korea; sarahlee0801@gmail.com (S.L.); \\ pjsldh@naver.com (D.L.) \\ 2 College of Korean Medicine, Gachon University, Seongnam 13120, Korea; kkang@gachon.ac.kr \\ 3 Institute of Green Bio Science \& Technology, Seoul National University, Pyeong Chang 232-916, Korea; \\ jangts@snu.ac.kr \\ 4 College of Pharmacy, Yeungnam University, Gyeongsan, Gyeongbuk 38541, Korea; jwnam@yu.ac.kr \\ 5 Department of Food and Nutrition, Gachon University, Seongnam 13120, Korea; skysea@gachon.ac.kr \\ * Correspondence: khkim83@skku.edu; Tel.: +82-31-290-7700
}

Received: 25 August 2017; Accepted: 20 September 2017; Published: 21 September 2017

\begin{abstract}
The edible fungus Phellinus baumii Pilat (Hymenochaetaceae) has been used in Korean traditional medicines for strengthening health and prolonging life. An extract of the fruiting bodies of $P$. baumii was subjected to bioassay-guided fractionation based on its anti-inflammatory effects in lipopolysaccharide (LPS)-stimulated RAW264.7 cells. The resulting fractions were chemically investigated, leading to isolation of three phenolic compounds (1-3), a sesquiterpene (4), two steroids (5-6), a fatty acid (7), and a cerebroside (8). Spectroscopic analyses including 1D and 2D NMR spectroscopy and LC/MS were used to determine their chemical structures. Compounds 2, 4, 5, 7 and 8 were identified in P. baumii for the first time. Since all compounds were isolated from active fractions with anti-inflammatory activity, their ability to inhibit LPS-stimulated nitric oxide (NO) production in RAW264.7 cells were evaluated in vitro. Compounds 1, 2, 3, 5 and 7 inhibited LPS-stimulated NO production, and compounds $1-3$ had IC I0 $_{5}$ values $<10 \mu \mathrm{M}$. Treatment of LPS-stimulated RAW264.7 cells with compounds 1-3 inhibited phosphorylation of IKK $\alpha$ and IKB $\alpha$. In addition, treatment of compounds 1-3 reduced LPS-induced increases of nuclear factor-kappa B (NF- $k B$ ) p65, iNOS and COX-2 protein expressions. Collectively, compounds 1-3 inhibited NF-kB-dependent inflammation in RAW264.7 cells. Thus, P. baumii is a potential source of natural anti-inflammatory agents, and active compounds 1-3 could be promising lead compounds for the development of novel anti-inflammatory agents.
\end{abstract}

Keywords: Phellinus baumii; Hymenochaetaceae; bioactivity-guided isolation; anti-inflammation; NO; NF-kappaB

\section{Introduction}

Phellinus baumii Pilat, a fungus belonging to the family Hymenochaetaceae, is an edible mushroom commonly known as "Sanghuang" in Korea [1,2]. The fruiting bodies of P. baumii have traditionally been included in the diet and in medicines in Asian countries such as Korea, China, and Japan [1-5]. P. baumii and other mushrooms of the genus Phellinus are well known to strengthen health and prolong life [6-10]. The traditional use of P. baumii has been verified both in vivo and in vitro [11-13], which provides strong evidence supporting its expanded use in the development of functional foods.

Extracts of P. baumii have been identified as potential modulators of oxidative stress, inflammation, and immunity, and have been reported to have various biological activities, including anti-obesity, 
anti-platelet, and hypoglycemic properties [7,10,12-15]. Although many chemical analyses have been published on Phellinus fungi such as P. linteus, the chemical constituents and significant metabolites of P. baumii have been relatively uninvestigated. Previous studies have demonstrated that polysaccharides isolated from P. baumii can inhibit tumor growth and metastasis [7,15], and other reports have noted the nuclear factor-kappa B (NF-kB) inhibitory effects of phenolic compounds and anti-influenza activities of polyphenols isolated from P. baumii $[10,16]$.

In our continuing efforts to discover bioactive secondary metabolites from Korean wild mushrooms [17-22], we have found that an ethanolic $(\mathrm{EtOH})$ extract of the fruiting bodies of P. baumii can inhibit nitric oxide (NO) production in lipopolysaccharide (LPS)-stimulated RAW264.7 cells. In this study, we used a bioactivity-guided isolation technique to identify metabolites from this EtOH extract with anti-inflammatory activity in LPS-stimulated RAW264.7 cells. Our chemical analysis led to the isolation and identification of three phenolic compounds (1-3), a sesquiterpene (4), two steroids (5-6), a fatty acid (7), and a cerebroside (8) with anti-inflammatory activity from the active fractions. Herein, we report the bioactivity-guided isolation and structural elucidation of compounds 1-8, along with their anti-inflammatory activities and underlying mechanisms of action.

\section{Results \& Discussion}

\subsection{Bioactivity-Guided Fractionation for Anti-Inflammatory Effects}

Dried and chopped fungal material was extracted with 60\% aqueous $\mathrm{EtOH}$ at room temperature and then filtered. The filtrate was evaporated under reduced pressure with a rotavapor to obtain a crude EtOH extract. In our screening test, the EtOH extract inhibited NO production in a dose-dependent manner in LPS-stimulated RAW264.7 cells, with an $\mathrm{IC}_{50}$ value of $56.9 \pm 1.2 \mu \mathrm{g} / \mathrm{mL}$, and no significant cell death was observed up to the concentration of $100 \mu \mathrm{g} / \mathrm{mL}$ (Figure 1).

(A)

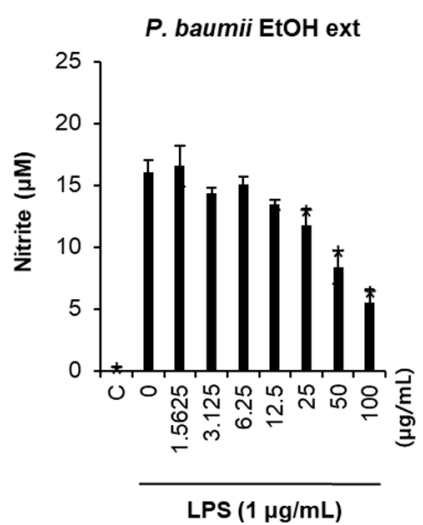

(B)

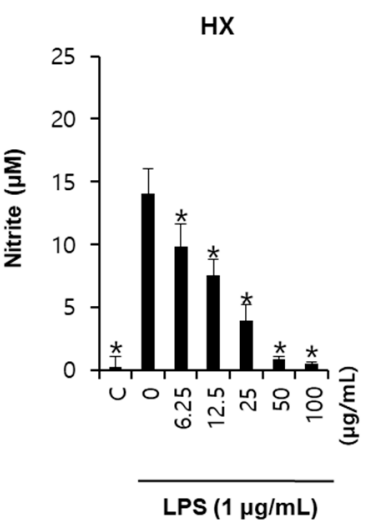

(C)

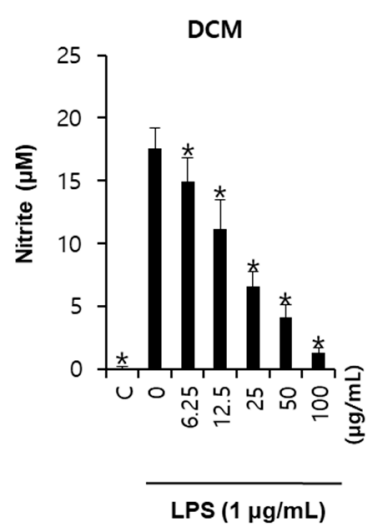

Figure 1. Anti-inflammatory effects of the $\mathrm{EtOH}$ extract of P. baumii and its fractions (hexane (HX) and dichloromethane (DCM) fractions): inhibition of lipopolysaccharide (LPS)-induced NO production in RAW264.7 mouse macrophages. (A-C) Inhibitory effects of the EtOH extract of P. baumii (A) and its hexane (B) and dichloromethane (C) fractions on LPS-induced NO production in RAW264.7 mouse macrophages. The cells were pretreated with the indicated concentrations of samples for $2 \mathrm{~h}$ and then exposed to $1 \mu \mathrm{g} / \mathrm{mL}$ LPS for $24 \mathrm{~h} .{ }^{*} p<0.05$ compared to the LPS-treated value.

The EtOH extract was then solvent-partitioned for bioassay-guided fractionation with hexane, dichloromethane $\left(\mathrm{CH}_{2} \mathrm{Cl}_{2}\right)$, ethyl acetate (EtOAc), and $n$-butanol, yielding soluble fractions of hexane $(\mathrm{HX}), \mathrm{CH}_{2} \mathrm{Cl}_{2}$ (DCM), EtOAc (EA), and $n$-butanol $(\mathrm{BuOH})$, respectively. Prior to investigating the anti-inflammatory effects of the four solvent-partitioned fractions, we examined the cellular toxicity of these fractions in RAW264.7 cells with MTT assay [23-26]. No significant cell death was observed for the HX, DCM, and BuOH fractions up to concentrations of $50 \mu \mathrm{g} / \mathrm{mL}$, while the EA fraction caused 
cell death at a concentration of $50 \mu \mathrm{g} / \mathrm{mL}$ (data not shown). The effects of the three fractions (HX, DCM, and BuOH fractions) without cellular toxicity on NO level were assessed in LPS-stimulated RAW264.7 cells (Figure 1). The HX and DCM fractions significantly inhibited NO production in a dose-dependent manner, with $\mathrm{IC}_{50}$ values of $13.8 \pm 1.2 \mu \mathrm{g} / \mathrm{mL}$ and $18.9 \pm 1.7 \mu \mathrm{g} / \mathrm{mL}$, respectively, while the $\mathrm{BuOH}$ fraction had no effect. These results inspired us to thoroughly investigate the two active fractions for anti-inflammatory constituents that inhibited NO production.

\subsection{Chemical Investigation and Identification of the Active Compounds}

The DCM fraction was subjected to repeated column chromatography and semi-preparative HPLC purification, which resulted in the isolation of five compounds (1-4 and 8). The HX fraction was chemically analyzed using the same method, which led to the isolation of three compounds (5-7). The structures of the isolates were determined using spectroscopic methods including 1D and 2D NMR spectroscopy and LC/MS (Figure 2). Compounds 1-8 were identified as 3,4-dihydroxybenzaldehyde (1) [27], 4-(4-hydroxyphenyl)-3-buten-2-one (2) [28], 4-(3,4-dihydroxyphenyl)-3-buten-2-one (3) [27], 3ß-hydroxycinnamolide (4) [29], 9,11-dehydroergosterol peroxide (5) [30], ergosterol peroxide (6) [30], ethyl linoleate (7) [31], and (2R)- $N$ [(1S,2R,3E,7E)-1-[( $\beta$-D-glucopyranosyloxy)methyl]-2-hydroxy-8-methyl-3,7-heptadecadien-1-yl]-2hydroxy-hexadecanamide (8) [32] through comparison of their obtained spectroscopic data with reported values, as well as LC/MS analysis. To the best of our knowledge, compounds 2, 4, 5, 7 and 8 were identified from P. baumii for the first time in this study.

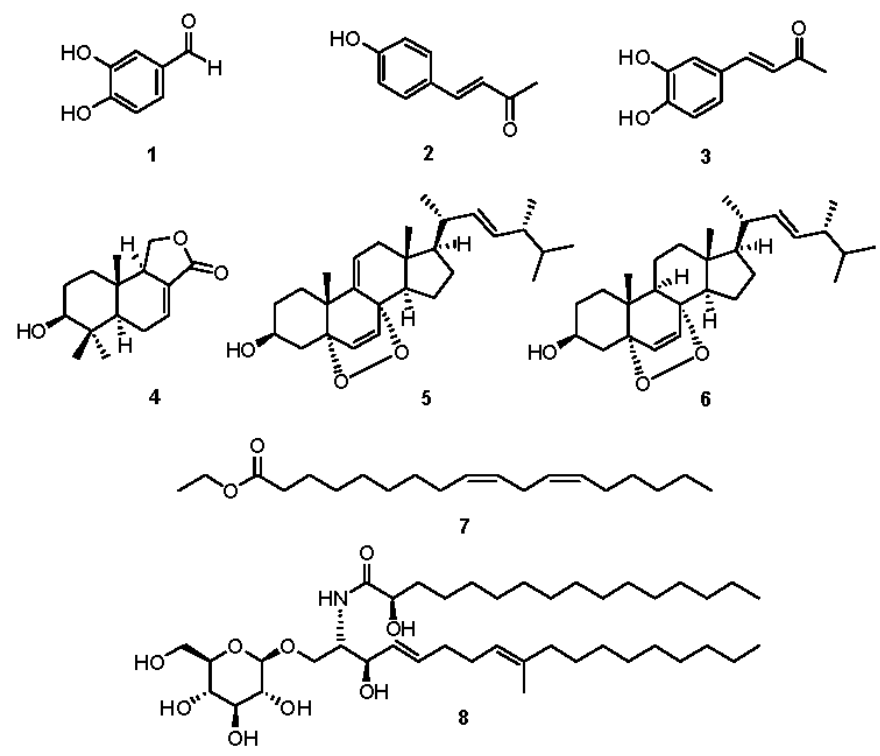

Figure 2. Chemical structures of compounds 1-8.

\subsection{Effects of Compounds 1-8 on NO Production}

Since all isolated compounds (1-8) were purified from active fractions that inhibited NO production, these compounds were then tested individually for their ability to inhibit NO production in LPS-activated RAW264.7 macrophages as a measure of their anti-inflammatory effects. No cytotoxic effects were noted for compounds 1-8 at concentrations up to $50 \mu \mathrm{M}$ (data not shown), and these non-toxic concentrations were used for subsequent anti-inflammatory activity tests. Compounds 1, 2, 3, 5 and 7 inhibited LPS-stimulated NO production (Figure 3). Among them, compounds 1, 2 and 3 significantly inhibited NO production in LPS-activated RAW264.7 macrophages, with IC $_{50}$ values of $9.1 \pm 0.1,0.8 \pm 0.1$, and $0.7 \pm 0.2 \mu \mathrm{M}$, respectively. Further mechanistic studies were performed with these three compounds, since their $\mathrm{IC}_{50}$ values were less than $10 \mu \mathrm{M}$. 

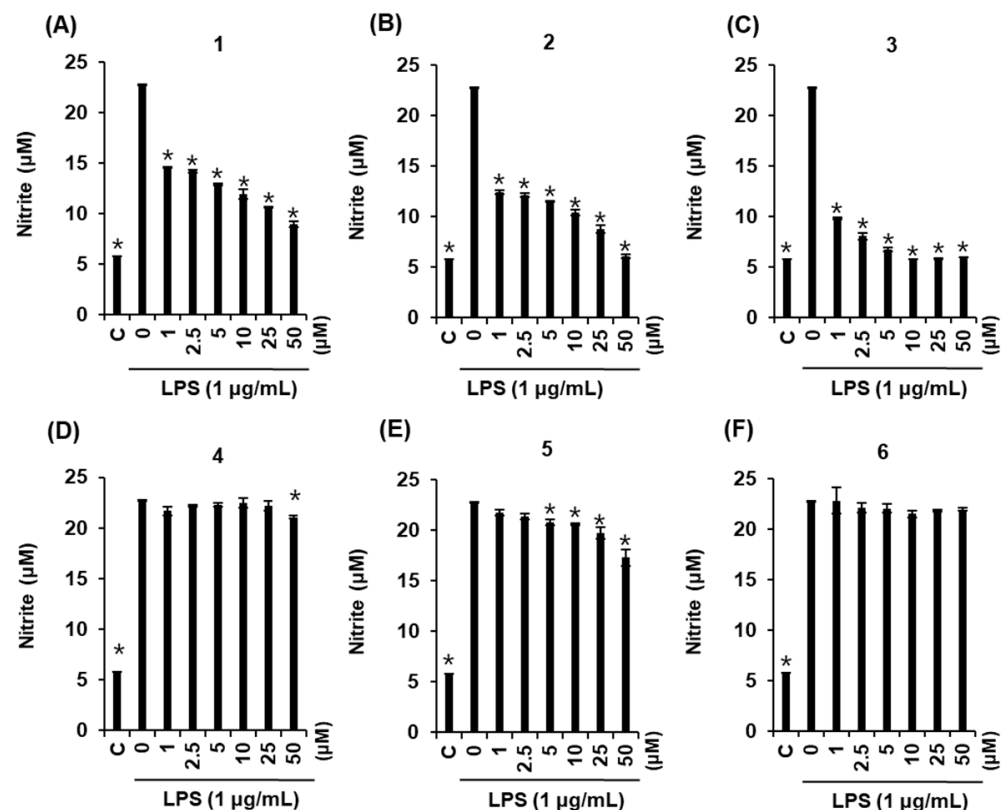

(E)

5
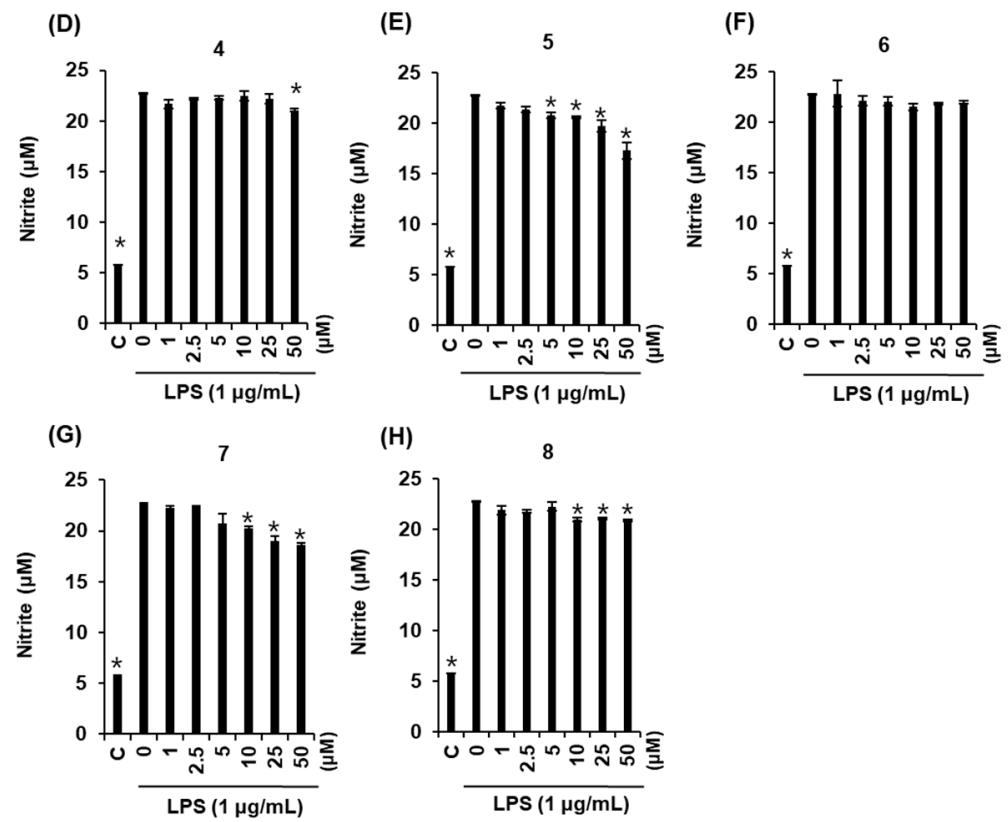

Figure 3. Anti-inflammatory effects of the isolated compounds: inhibition of LPS-induced NO production in RAW264.7 mouse macrophages. Inhibitory effects of isolated compounds 1 (A), 2 (B), $3(\mathrm{C}), 4(\mathrm{D}), 5(\mathrm{E}), 6(\mathrm{~F}), 7(\mathrm{G})$, and $8(\mathrm{H})$ on LPS-induced NO production in RAW264.7 mouse macrophages. The cells were pretreated with the indicated concentrations of samples for $2 \mathrm{~h}$ and then exposed to $1 \mu \mathrm{g} / \mathrm{mL}$ LPS for $24 \mathrm{~h} .{ }^{*} p<0.05$ compared to the LPS-treated value.

\subsection{Effects of Compounds 1-3 on Proteins Associated with Inhibition of NF-kB in LPS-Stimulated RAW264.7 Mouse Macrophages}

To further confirm the anti-inflammatory properties of compounds 1, 2 and 3, we investigated their effects on the phosphorylation of IKK $\alpha$ and I $\mathrm{B} \alpha \alpha$, and protein expressions of NF-kB p65, iNOS, and COX-2, which are involved in the pathogenesis of chronic inflammatory diseases. In un-activated cells, NF- $\mathrm{BB}$ localizes to the cytoplasm, and the I $\kappa \mathrm{B}$ proteins bind to NF- $\mathrm{KB}$ and inhibit its nuclear localization and activation signals $[33,34]$. The phosphorylation of I $\kappa B$ proteins is a key step in the activation of NF- $\mathrm{KB}$ and is regulated by IKB kinases (IKKs) [35], while IKK activity is induced by activators of the NF- $k B$ pathways [33,34]. Compounds $\mathbf{1}, \mathbf{2}$ and $\mathbf{3}$ inhibited the phosphorylation of IKK $\alpha$ and IKB $\alpha$ in LPS-stimulated RAW264.7 cells. Collectively, compounds 1, 2, and 3 inhibited the NF-KB-dependent inflammation pathway in RAW264.7 cells (Figure 4).

$\mathrm{NF}-\mathrm{KB}$ also activates the expression of enzymes that contribute to the pathogenesis of the inflammatory process, including iNOS and COX-2, the latter of which generates prostanoids [36]. Compounds 1, 2 and 3 also significantly reduced the expression of iNOS and COX-2 (Figure 4), reflecting the inhibition of the expression of these inflammatory enzymes by NF- $\mathrm{kB}$ deactivation.

The anti-inflammatory components of $P$. baumii have not been widely studied yet. Recently, a related study described the phenolic compounds of P. baumii with NF-kB inhibitory effects in PC-3 
cells [10]. These phenolic compounds (dihydroflavones and hispidin derivatives) were examined for their inhibitory effects on NF-KB activity in a luciferase gene reporter assay, and the $\mathrm{IC}_{50}$ values of the active compounds were approximately $20 \mu \mathrm{M}$ higher than those of active phenolic compounds identified in the present study [10]. Ultimately, we identified components of P. baumii with higher effectiveness in anti-inflammation.

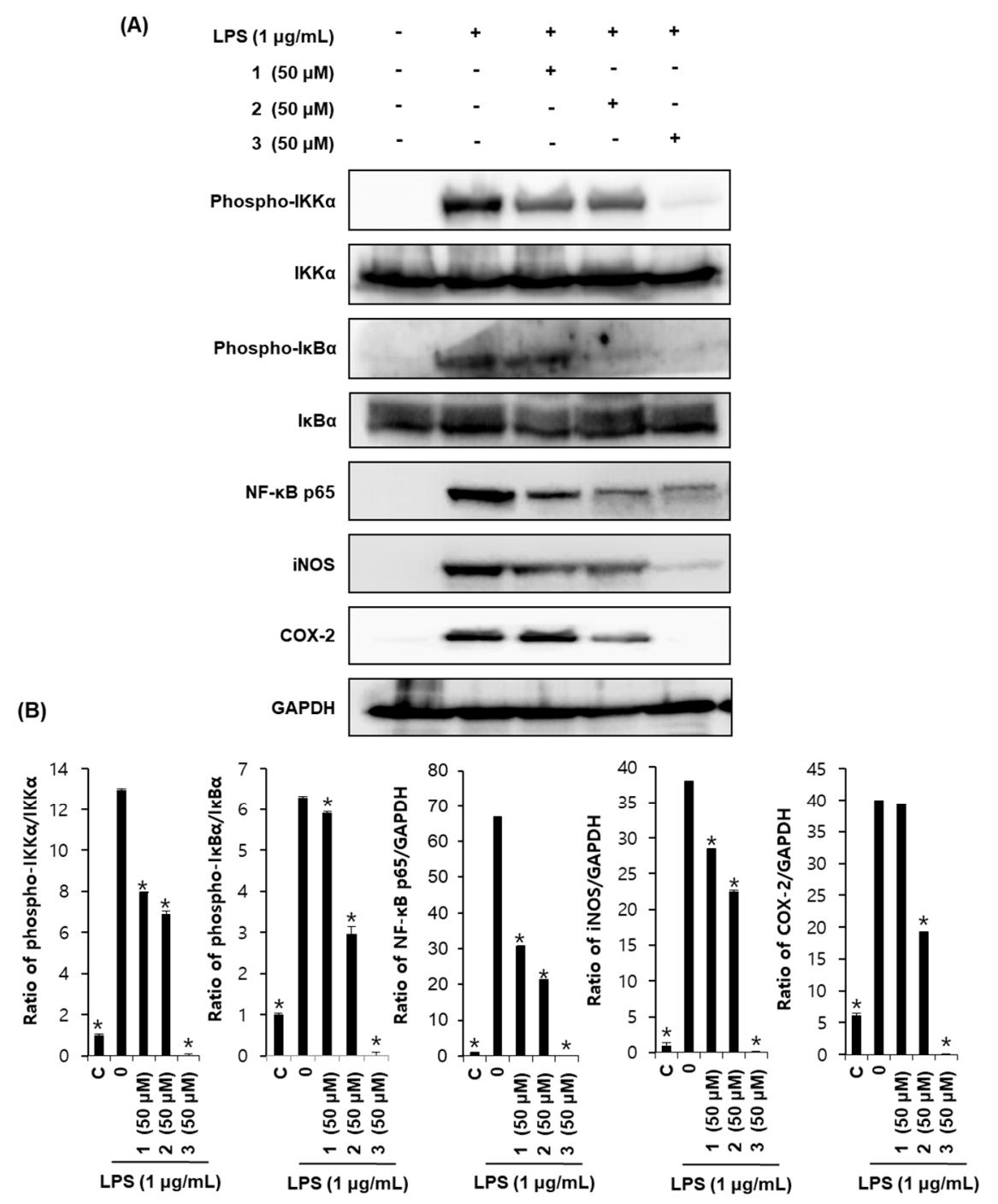

Figure 4. Effects of compounds 1, 2 and 3 on the expression of proteins associated with inhibition of NF- $\kappa$ B in LPS-stimulated RAW264.7 mouse macrophages (A). Each bar graph presents the densitometric quantification of western blot bands $(\mathbf{B}){ }^{*} p<0.05$ compared to the LPS-treated value.

\section{Materials and Methods}

\subsection{General Experimental Procedures}

Ultraviolet (UV) spectra were acquired on an Agilent 8453 UV-visible spectrophotometer (Agilent Technologies, Santa Clara, CA, USA). NMR spectra were obtained with a Bruker AVANCE III 700 NMR spectrometer operating at $700 \mathrm{MHz}\left({ }^{1} \mathrm{H}\right)$ and $175 \mathrm{MHz}\left({ }^{13} \mathrm{C}\right)$ (Bruker, Billerica, MA, USA). Semipreparative HPLC was conducted with a Shimadzu Prominence HPLC System equipped with SPD-20A/20AV-series Prominence HPLC UV-Vis detectors (Shimadzu, Tokyo, Japan). LC/MS analysis was performed on an Agilent 1200-series HPLC system with a diode array detector and a 6130-series ESI mass spectrometer with an analytical Kinetex C18 $100 \AA$ column $(100 \mathrm{~mm} \times 2.1 \mathrm{~mm}$ i.d., $5 \mu \mathrm{m})$ 
(Phenomenex, Torrance, CA, USA). Column chromatography was performed with silica gel 60, 230-400 mesh (Merck, Darmstadt, Germany). Thin-layer chromatography (TLC) was conducted with precoated silica gel $\mathrm{F}_{254}$ plates and reverse-phase (RP)-18 $\mathrm{F}_{254 \mathrm{~s}}$ plates (Merck, Kenilworth, NJ, USA). Spots on TLC were detected with UV light and heat after the plates were dipped in anisaldehyde-sulfuric acid.

\subsection{Fungus Material}

Fresh fruiting bodies of P. baumii were purchased from DDLE A CHE Co., Ltd. (Cheonan-si, Chungcheongnam-do, Korea), having been cultivated in Jungdo-ri, Sanyang-myeon, Munkyung, Gyeongsangbuk-do, Korea, in April 2016. Samples of fungal material were identified by one of the authors (Hae-Jeung Lee). A voucher specimen (SKKU 2016-04-SH) has been deposited in the herbarium of the School of Pharmacy, Sungkyunkwan University, Suwon, Korea.

\subsection{Extraction, Fractionation, and Purification Methods}

The dried and chopped fungal material (150 g) was extracted with 60\% aqueous EtOH three times (each $3 \mathrm{~L} \times 24 \mathrm{~h}$ ) at room temperature. Extracts were filtered, and the filtrate was evaporated under reduced pressure with a rotavapor to obtain a crude EtOH extract (10.0 g). The extract was suspended in distilled water $(700 \mathrm{~mL})$ and $\mathrm{MeOH}(30 \mathrm{~mL})$ and successively solvent-partitioned with hexane, dichloromethane, ethyl acetate, and $n$-butanol, yielding soluble layers of hexane (HX) $(0.9 \mathrm{~g})$, $\mathrm{CH}_{2} \mathrm{Cl}_{2}$ (DCM) $(0.5 \mathrm{~g})$, EtOAc (EA) $(0.4 \mathrm{~g})$, and $n$-butanol (BuOH) $(1.1 \mathrm{~g})$. The HX and DCM fractions significantly inhibited NO production in a dose-dependent manner in LPS-stimulated RAW264.7 cells.

The DCM fraction $(0.5 \mathrm{~g})$ was subjected to silica gel column chromatography (CC) $\left(\mathrm{CH}_{2} \mathrm{Cl}_{2} /\right.$ $\mathrm{MeOH}$, from 100:1 to 1:1), yielding 6 fractions (Fr. A1-A6). Fr. A4 (23.5 mg) was purified by semi-preparative HPLC $(32 \% \mathrm{MeOH})$ with a Phenomenex Luna phenyl-hexyl column $(250 \mathrm{~mm} \times$ $10 \mathrm{~mm}$ i.d., flow rate: $2 \mathrm{~mL} / \mathrm{min}$ ) to yield compounds $\mathbf{1}\left(t_{R} 18.0 \mathrm{~min}, 2.8 \mathrm{mg}\right.$ ) and $\mathbf{3}\left(t_{R} 37.5 \mathrm{~min}, 3.3 \mathrm{mg}\right)$. Fr. A2 $(22.7 \mathrm{mg})$ was also purified by semi- preparative HPLC (gradient solvent system from $50 \%$ $\mathrm{MeOH}$ to $100 \% \mathrm{MeOH})$ with a Phenomenex Luna phenyl-hexyl column $(250 \mathrm{~mm} \times 10 \mathrm{~mm}$ i.d., flow rate: $2 \mathrm{~mL} / \mathrm{min}$ ) to yield compounds $2\left(t_{R} 17.0 \mathrm{~min}, 1.1 \mathrm{mg}\right)$ and $4\left(t_{R} 24.0 \mathrm{~min}, 1.7 \mathrm{mg}\right)$. Compound 8 $\left(t_{R} 39.0 \mathrm{~min}, 0.7 \mathrm{mg}\right)$ was purified from Fr. A5 (41.5 mg) using the same method.

The HX fraction $(0.9 \mathrm{~g})$ was subjected to silica gel CC (hexane/EtOAc, from 5:1 to 1:1) to yield 5 fractions (Fr. B1-B5). Fr. B4 (14.2 mg) was purified by semi-preparative HPLC (92\% MeOH) with a Phenomenex Luna phenyl-hexyl column $(250 \mathrm{~mm} \times 10 \mathrm{~mm}$ i.d., flow rate: $2 \mathrm{~mL} / \mathrm{min})$, and compounds $5\left(t_{R} 29.0 \mathrm{~min}, 0.6 \mathrm{mg}\right)$ and $6\left(t_{R} 34.5 \mathrm{~min}, 1.6 \mathrm{mg}\right)$ were obtained. Fr. B1 $(15.8 \mathrm{mg})$ was separated on a Phenomenex Luna phenyl-hexyl column ( $250 \mathrm{~mm} \times 10 \mathrm{~mm}$ i.d., flow rate: $2 \mathrm{~mL} / \mathrm{min})$ in a semi-preparative HPLC system (gradient solvent system from $80 \% \mathrm{MeOH}$ to $100 \% \mathrm{MeOH}$ ) to yield compound 7 ( $\left.t_{R} 43.0 \mathrm{~min}, 2.6 \mathrm{mg}\right)$.

\subsection{Cell Culture and MTT Cell Viability Assay}

RAW264.7 mouse macrophages were purchased from the American Type Culture Collection (Rockville, MD, USA). The cells were cultured in DMEM (Cellgro, Manassas, VA, USA) supplemented with $10 \%$ FBS, $1 \%$ penicillin/streptomycin (Invitrogen Co., Grand Island, NY, USA), and $4 \mathrm{mM}$ L-glutamine in an atmosphere of $5 \% \mathrm{CO}_{2}$ at $37^{\circ} \mathrm{C}$. Cell viability was determined with an Ez-Cytox cell viability detection kit. When the cells were approximately $80 \%$ confluent, they were seeded in 96 -well culture plates at $1 \times 10^{5}$ cells per well and incubated for $24 \mathrm{~h}$ for adhesion. Then cells were treated with the control $(0.5 \% \mathrm{DMSO})$ or with indicated concentrations of the EtOH extract of P. baumii, its fractions, and isolated compounds 1-8. After cells had been incubated with these treatments for $24 \mathrm{~h}, 10 \mu \mathrm{L}$ of Ez-Cytox reagent was added to each well and incubated for $2 \mathrm{~h}$. Cell viability was determined from the absorbance at $450 \mathrm{~nm}$ measured with a microplate reader (PowerWave XS; Bio-Tek Instruments, Winooski, VT, USA). 


\subsection{Measurement of Nitric Oxide Production}

Escherichia coli LPS (strain 055:B5) was purchased from Sigma Aldrich (Saint Louis, MO, USA). NO production was determined by the Griess reaction, which measures the accumulation of nitrite in the culture medium. When the cells were approximately $80 \%$ confluent, they were seeded in 96-well culture plates at $1 \times 10^{5}$ cells per well and incubated for $24 \mathrm{~h}$ for adhesion. The cells were then pretreated with phenol red-free medium containing the control ( $0.5 \% \mathrm{DMSO})$ or the indicated concentrations of compounds 1-8 for $2 \mathrm{~h}$ and then exposed to $1 \mu \mathrm{g} / \mathrm{mL}$ E. coli LPS (strain 055:B5) for $24 \mathrm{~h}$. The supernatant $(80 \mu \mathrm{L})$ was collected, mixed with an equal volume $(80 \mu \mathrm{L})$ of Griess reagent (1\% sulfanilamide, $5 \%$ phosphoric acid, and 0.1\% N-(1-naphthyl)-ethylenediamine), and incubated in the dark at room temperature for $10 \mathrm{~min}$. The absorbance at $540 \mathrm{~nm}$ was measured with a microplate reader (PowerWave XS; Bio-Tek Instruments, Winooski, VT, USA). Sodium nitrite was used to generate a standard reference curve.

\subsection{Western Blotting Analysis}

RAW264.7 cells seeded in 6-well plates were treated with compounds 1, 2 and 3 (50 $\mu \mathrm{M})$. After the cells were incubated with these treatments for $2 \mathrm{~h}, 1 \mu \mathrm{g} / \mathrm{mL}$ E. coli LPS (strain 055:B5) was added to each well and incubated for $24 \mathrm{~h}$. Then cells were lysed with RIPA buffer $(20 \mathrm{mM}$ Tris- $\mathrm{HCl}$ (pH 7.5), $150 \mathrm{mM} \mathrm{NaCl}, 1 \mathrm{mM} \mathrm{Na} 2$ EDTA, $1 \mathrm{mM}$ EGTA, 1\% NP-40, 1\% sodium deoxycholate, $2.5 \mathrm{mM}$ sodium pyrophosphate, $1 \mathrm{mM}$ beta-glycerophosphate, $1 \mathrm{mM} \mathrm{Na} \mathrm{VO}_{4}, 1 \mu \mathrm{g} / \mathrm{mL}$ leupeptin, Cell Signaling, MA, USA) supplemented with $1 \mathrm{mM}$ phenylmethylsulfonyl fluoride (PMSF) immediately before use. Protein concentrations were determined with a Pierce ${ }^{\mathrm{TM}}$ BCA Protein Assay Kit (Thermo Scientific, Waltham, MA, USA). Equal amounts (20 $\mu \mathrm{g} /$ lane) of protein (whole-cell extracts) were separated by electrophoresis in a 10\% sodium dodecyl sulfate-polyacrylamide gel and transferred onto PVDF transfer membranes. Specific proteins were analyzed with epitope-specific primary antibodies to NF-кB p65 (\#4764), iNOS (\#13120), COX-2 (\#4842), IкB $\alpha$ (\#9242), phospho-IkB $\alpha$ (\#2859), IKK $\alpha$ (\#2682), phospho-IKK $\alpha$ (\#2697), glyceraldehyde 3-phosphate dehydrogenase (\#2118), and horseradish peroxidase (HRP)-conjugated anti-rabbit antibodies (Cell Signaling, Boston, MA, USA). Bound antibodies were detected with ECL Advance Western Blotting Detection Reagents (GE Healthcare, Little Chalfont, UK) and visualized with a FUSION Solo Chemiluminescence System (PEQLAB Biotechnologie GmbH, Erlangen Germany).

\subsection{Statistical Analysis}

Statistical significance was determined using analysis of variance followed by multiple comparison tests with Bonferroni adjustment. A $p$ value of less than 0.05 was considered statistically significant.

\section{Conclusions}

In the current study, we found that an EtOH extract of the fruiting bodies of P. baumii inhibited NO production in LPS-activated RAW264.7 macrophages. This EtOH extract was thus examined for its active constituents, and eight compounds were identified (1-8), five of which $(\mathbf{2}, 4,5,7$ and 8$)$ were identified in the fungus P. baumii for the first time. Among the compounds identified in this work, compounds 1, 2 and 3 significantly inhibited NO production in LPS-activated RAW264.7 macrophages, with $\mathrm{IC}_{50}$ values of $9.1 \pm 0.1,0.8 \pm 0.1$ and $0.7 \pm 0.2 \mu \mathrm{M}$, respectively. These three active compounds inhibited the phosphorylation of IKK $\alpha$ and $I \kappa B \alpha$. In addition, treatment of compounds $1-3$ reduced LPS-induced increases of NF- $\mathrm{B}$ p 65, iNOS, and COX-2 protein expressions. These findings provide experimental evidence that compounds 1, 2 and 3 could contribute to the health benefits of $P$. baumii as an anti-inflammatory agent. 
Acknowledgments: This research was supported by the Basic Science Research Program through the National Research Foundation of Korea (NRF) funded by the Ministry of Science, ICT, \& Future Planning (2015R1C1A1A02037383). This study was supported by the Korea Food Research Institute (EO164500-01), Republic of Korea. This work was supported by Korea Institute of Planning and Evaluation for Technology in Food, Agriculture, Forestry and Fisheries (IPET) through High Value-added Food Technology Development Program, funded by Ministry of Agriculture, Food and Rural Affairs (MAFRA) (grant number 116019-3).

Author Contributions: H.-J.L., K.S.K. and K.H.K. conceived and designed the experiments; S.L. and D.L. performed the experiments; T.S.J., K.S.K., J.-W.N. and K.H.K. analyzed the data; K.S.K. and H.-J.L. contributed reagents / materials / analysis tools; K.S.K. and K.H.K. wrote the paper.

Conflicts of Interest: The authors declare no conflict of interest.

\section{References}

1. Lim, Y.; Lee, S.; Kim, J.Y.; Shin, J.H.; Kwon, O.A. Phellinus baumii-Based supplement containing Salvia miltiorrhiza Bunge improves atherothrombotic profiles through endothelial nitric oxide synthase and cyclooxygenase pathways in vitro and in vivo. J. Funct. Foods 2016, 24, 231-243. [CrossRef]

2. Lemieszek, M.K.; Langner, E.; Kaczor, J.; Kandefer-Szerszen, M.; Sanecka, B.; Mazurkiewicz, W.; Rzeski, W. Anticancer effects of fraction isolated from fruiting bodies of Chaga medicinal mushroom, Inonotus obliquus (Pers.:Fr.) Pilát (Aphyllophoromycetideae): In vitro studies. Int. J. Med. Mushrooms 2011, 13, 131-143. [CrossRef] [PubMed]

3. Noh, J.R.; Lee, I.K.; Ly, S.Y.; Yang, K.J.; Gang, G.T.; Kim, Y.H.; Hwang, J.H.; Yun, B.S.; Lee, C.H. A Phellinus baumii extract reduces obesity in high-fat diet-fed mice and absorption of triglyceride in lipid-loaded mice. J. Med. Food 2011, 14, 209-218. [CrossRef] [PubMed]

4. Zhu, T.; Kim, S.H.; Chen, C.Y. A medicinal mushroom: Phellinus linteus. Curr. Med. Chem. 2008, 15, 1330-1335. [CrossRef] [PubMed]

5. Lee, I.K.; Yun, B.S. Styrylpyrone-class compounds from medicinal fungi Phellinus and Inonotus spp., and their medicinal importance. J. Antibiot. 2011, 64, 349-359. [CrossRef] [PubMed]

6. Jang, B.S.; Kim, J.C.; Bae, J.S.; Rhee, M.H.; Jang, K.H.; Song, J.C.; Kwon, O.D.; Park, S.C. Extracts of Phellinus gilvus and Phellinus baumii inhibit pulmonary inflammation induced by lipopolysaccharide in rats. Biotechnol. Lett. 2004, 26, 31-33. [CrossRef] [PubMed]

7. Liu, M.M.; Zeng, P.; Li, X.T.; Shi, L.G. Antitumor and immunomodulation activities of polysaccharide from Phellinus baumii. Int. J. Biol. Macromol. 2016, 91, 1199-1205. [CrossRef] [PubMed]

8. Cho, J.H.; Cho, S.D.; Hu, H.; Kim, S.H.; Lee, S.K.; Lee, Y.S.; Kang, K.S. The roles of ERK1/2 and p38 MAP kinases in the preventive mechanisms of mushroom Phellinus linteus against the inhibition of gap junctional intercellular communication by hydrogen peroxide. Carcinogenesis 2002, 23, 1163-1169. [CrossRef] [PubMed]

9. Ajith, T.; Janardhanan, K. Cytotoxic and antitumor activities of a polypore macrofungus, Phellinus rimosus (Berk) Pilat. J. Ethnopharmacol. 2003, 84, 157-162. [CrossRef]

10. Wu, C.S.; Lin, Z.M.; Wang, L.N.; Guo, D.X.; Wang, S.Q.; Liu, Y.Q.; Yuan, H.Q.; Lou, H.X. Phenolic compounds with NF-kB inhibitory effects from the fungus Phellinus baumii. Bioorg. Med. Chem. Lett. 2011, 21, 3261-3267. [CrossRef] [PubMed]

11. Yayeh, T.; Oh, W.J.; Park, S.C.; Kim, T.H.; Cho, J.Y.; Park, H.J.; Lee, I.K.; Kim, S.K.; Hong, S.B.; Yun, B.S.; et al. Phellinus baumii ethyl acetate extract inhibits lipopolysaccharide-induced iNOS, COX-2, and proinflammatory cytokine expression in RAW264.7 cells. J. Nat. Med. 2012, 66, 49-54. [CrossRef] [PubMed]

12. Lee, I.K.; Han, M.S.; Lee, M.S.; Kim, Y.S.; Yun, B.S. Styrylpyrones from the medicinal fungus Phellinus baumii and their antioxidant properties. Bioorg. Med. Chem. Lett. 2010, 20, 5459-5461. [CrossRef] [PubMed]

13. Kamruzzaman, S.M.; Endale, M.; Oh, W.J.; Park, S.C.; Kim, T.H.; Lee, I.K.; Cho, J.Y.; Park, H.J.; Kim, S.K.; Yun, B.S.; et al. Antiplatelet activity of Phellinus baummii methanol extract is mediated by cyclic AMP elevation and inhibition of collagen-activated integrin- $\alpha \mathrm{IIb} \beta 3$ and MAP kinase. Phytother. Res. 2011, 25, 1596-1603. [CrossRef] [PubMed]

14. Hwang, H.J.; Kim, S.W.; Lim, J.M.; Joo, J.H.; Kim, H.O.; Kim, H.M.; Yun, J.W. Hypoglycemic effect of crude exopolysaccharides produced by a medicinal mushroom Phellinus baumii in streptozotocin-induced diabetic rats. Life Sci. 2005, 76, 3069-3080. [CrossRef] [PubMed] 
15. Han, S.B.; Lee, C.W.; Jeon, Y.J.; Hong, N.D.; Yoo, I.D.; Yang, K.H.; Kim, H.M. The inhibitory effect of polysaccharides isolated from Phellinus linteus on tumor growth and metastasis. Immunopharmacology 1999, 41, 157-164. [CrossRef]

16. Hwang, B.S.; Lee, I.K.; Choi, H.J.; Yun, B.S. Anti-influenza activities of polyphenols from the medicinal mushroom Phellinus baumii. Bioorg. Med. Chem. Lett. 2015, 25, 3256-3260. [CrossRef] [PubMed]

17. Suh, W.S.; Lee, S.R.; Kim, C.S.; Moon, E.; Kim, S.Y.; Choi, S.U.; Kang, K.S.; Lee, K.R.; Kim, K.H. A new monoacylglycerol from the fruiting bodies of Gymnopilus spectabilis. J. Chem. Res. 2016, 40, $156-159$. [CrossRef]

18. Lee, S.R.; Jung, K.; Noh, H.J.; Park, Y.J.; Lee, H.L.; Lee, K.R.; Kang, K.S.; Kim, K.H. A new cerebroside from the fruiting bodies of Hericium erinaceus and its applicability to cancer treatment. Bioorg. Med. Chem. Lett. 2015, 25, 5712-5715. [CrossRef] [PubMed]

19. Noh, H.J.; Yang, H.H.; Kim, G.S.; Lee, S.E.; Lee, D.Y.; Choi, J.H.; Kim, S.Y.; Lee, E.S.; Ji, S.H.; Kang, K.S.; et al. Chemical constituents of Hericium erinaceum associated with the inhibitory activity against cellular senescence in human umbilical vascular endothelial cells. J. Enzyme Inhib. Med. Chem. 2015, 30, 934-940. [CrossRef] [PubMed]

20. Kim, C.S.; Moon, E.; Choi, S.U.; Kim, S.Y.; Lee, K.R.; Kim, K.H. Cytotoxic and anti-inflammatory disulfide compounds from the fruiting bodies of Boletus pseudocalopus. J. Antibiot. 2015, 68, 414-416. [CrossRef] [PubMed]

21. Kim, K.H.; Choi, S.U.; Noh, H.J.; Zee, O.; Lee, K.R. Cytotoxic ergosterol derivatives from the mushroom Naematoloma fasciculare. Nat. Prod. Sci. 2014, 20, 76-79.

22. Lee, S.R.; Lee, S.; Moon, E.; Park, H.J.; Park, H.B.; Kim, K.H. Bioactivity-guided isolation of anti-inflammatory triterpenoids from the sclerotia of Poria cocos using LPS-stimulated Raw264.7 cells. Bioorg. Chem. 2017, 70, 94-99. [CrossRef] [PubMed]

23. Taher, M.; Aminuddin, A.; Susanti, D.; Aminudin, N.I.; On, S.; Ahmad, F.; Hamidon, H. Cytotoxic, anti-inflammatory and adipogenic effects of inophyllum $\mathrm{D}$, calanone, isocordato-oblongic acid, and morelloflavone on cell lines. Nat. Prod. Sci. 2016, 22, 122-128. [CrossRef]

24. Kim, J.; Lee, H.; Kang, K.S.; Chun, K.H.; Hwang, G.S. Protective effect of Korean Red Ginseng against glucocorticoid-induced osteoporosis in vitro and in vivo. J. Ginseng Res. 2015, 39, 46-53. [CrossRef] [PubMed]

25. Peng, Y.; Zhong, Y.; Li, G. Tubeimoside-1 suppresses breast cancer metastasis through downregulation of CXCR4 chemokine receptor expression. BMB Rep. 2016, 49, 502-507. [CrossRef] [PubMed]

26. Ko, W.; Sohn, J.H.; Kim, Y.C.; Oh, H. Viridicatol from marine-derived fungal strain Penicillium sp. SF-5295 exerts anti-inflammatory effects through inhibiting NF- $\kappa B$ signaling pathway on lipopolysaccharide-induced RAW264.7 and BV2 cells. Nat. Prod. Sci. 2015, 21, 240-247. [CrossRef]

27. Yoon, H.R.; Paik, Y.S. Antioxidative and prolyl endopeptidase inhibitory activities of the phenolic constituents isolated from Phellinus linteus. J. Korean Soc. Appl. Biol. Chem. 2010, 53, 652-656. [CrossRef]

28. Chakraborti, A.K.; Sharma, L.; Nayak, M.K. Demand-based thiolate anion generation under virtually neutral conditions: Influence of steric and electronic factors on chemo- and regioselective cleavage of aryl alkyl ethers. J. Org. Chem. 2002, 67, 6406-6414. [CrossRef] [PubMed]

29. Ayer, W.A.; Trifonov, L.S. Drimane sesquiterpene lactones from Peniophora polygonia. J. Nat. Prod. 1992, 55, 1454-1461. [CrossRef]

30. Chen, Y.K.; Kuo, Y.H.; Chiang, B.H.; Lo, J.M.; Sheen, L.Y. Cytotoxic activities of 9,11-dehydroergosterol peroxide and ergosterol peroxide from the fermentation mycelia of Ganoderma lucidum cultivated in the medium containing leguminous plants on Hep 3B cells. J. Agric. Food Chem. 2009, 57, 5713-5719. [CrossRef] [PubMed]

31. Le, J.; Lu, W.; Xiong, X.; Wu, Z.; Chen, W. Anti-inflammatory constituents from Bidens frondosa. Molecules 2015, 20, 18496-18510. [CrossRef] [PubMed]

32. Lee, S.R.; Lee, D.; Lee, H.J.; Noh, H.J.; Jung, K.; Kang, K.S.; Kim, K.H. Renoprotective chemical constituents from an edible mushroom, Pleurotus cornucopiae in cisplatin-induced nephrotoxicity. Bioorg. Chem. 2017, 71, 67-73. [CrossRef] [PubMed] 
33. Baldwin, A.S. The NF-кB and IкB proteins: New discoveries and insights. Annu. Rev. Immunol. 1996, 14, 649-681. [CrossRef] [PubMed]

34. Ghosh, S.; May, M.J.; Kopp, E.B. NF-кB and Rel proteins: Evolutionarily conserved mediators of immune responses. Annu. Rev. Immunol. 1998, 16, 225-260. [CrossRef] [PubMed]

35. Zandi, E.; Karin, M. Bridging the gap: Composition, regulation, and physiological function of the IKB kinase complex. Mol. Cell. Biol. 1999, 19, 4547-4551. [CrossRef] [PubMed]

36. Pahl, H.L. Activators and target genes of Rel/NF-kB transcription factors. Oncogene 1999, 18, $6853-6866$. [CrossRef] [PubMed]

Sample Availability: Not available.

(C) 2017 by the authors. Licensee MDPI, Basel, Switzerland. This article is an open access article distributed under the terms and conditions of the Creative Commons Attribution (CC BY) license (http:/ / creativecommons.org/licenses/by/4.0/). 